\title{
RUSSIAN FOOD IMPORT BAN - IMPACTS ON RURAL AND REGIONAL DEVELOPMENT IN FINLAND
}

\author{
Nina Hyytiä ${ }^{1}$
}

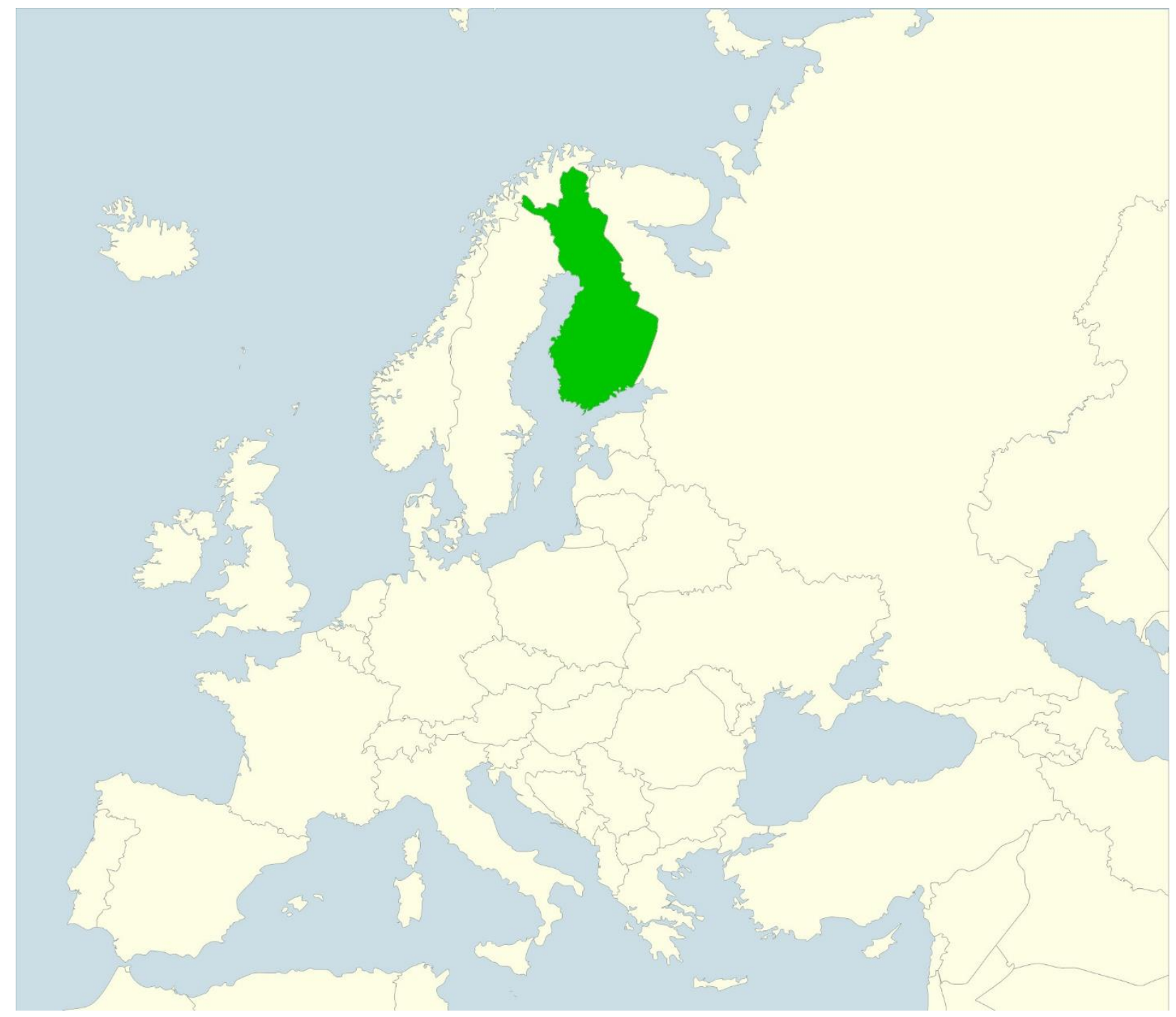

${ }^{1}$ Nina Hyytiä, D.Sc., University lecturer, Department of Economics and Management, University of Helsinki, Finland; e-mail: nina.hyytia@helsinki.fi, ORCID: 0000-0003-3204-4545. 
Abstract: This paper investigates the economic effects of the food import ban that Russia imposed vis-à-vis the European Union in 2014 on the development of two structurally different rural regions in Finland. A detailed, rural-urban dataset was compiled for use with a recursive dynamic computable general equilibrium model. In the medium run, the overall economic effects of the trade ban were negative for both regions, and the value added of agriculture and food industries fell notably. When the rigidities of capital availability were relaxed, regional GDP and employment increased in South Ostrobothnia as, for instance, metal industry and construction accelerated economic growth. In North Karelia, where agriculture and food industry account for a minor share of economy, other industries could not compensate the losses the ban caused. Accordingly, the impacts were dependent on the economic structure of the region.

Keywords: regional general equilibrium, rural development, agriculture, food industry, trade

Tiivistelmä: Tutkimuksessa tarkastellaan Venäjän asettaman elintarvikkeiden tuontikiellon taloudellisia vaikutuksia kahteen, talousrakenteeltaan erilaiseen maakuntaan Suomessa. Alueista koostettiin maaseutu- ja kaupunki- alueet erottelevat sosiaalisen tilinpidon matriisit, joita käytettiin aineistona rekursiivis-dynaamisessa yleisen tasapainon mallissa. Keskipitkällä aikavälillä tuontikiellon taloudelliset vaikutukset olivat negatiivisia kummassakin maakunnassa ja maa- ja elintarviketalouden arvonlisäys laski merkittävästi. Pidemmällä aikavälillä, kun pääomaa oli vapaammin saatavilla, alueellinen arvonlisäys ja työllisyys kasvoivat Etelä-Pohjanmaalla ja etenkin metalliteollisuus ja rakentaminen hyötyivät, kun tuotannontekijöitä vapautui maa- ja elintarviketaloudesta. Pohjois-Karjalassa, jossa maa- ja elintarviketaloudella on pieni osuus taloudesta, myös pitkän aikavälin vaikutukset olivat negatiiviset.

Asiasanat: alueellinen yleinen tasapaino, maaseudun kehitys, maa- ja elintarviketalous, kauppa

\section{Introduction}

Despite the gradual shifts in EU budget allocation to larger societal and global issues such as migration, security and knowledge enhancement investments, the Common Agricultural Policy (CAP) still accounts for $37 \%$ of the EU budget (European Union 2018). The rationale behind the high level of subsidies is not only the arguments directly related to food production and agricultural industry but also environmental concerns and rural and regional development targets. The European Commission $(2013,2017)$ argues that the CAP itself contributes importantly to job creation and rural area growth in Europe via its long-term objectives, i.e. viable food production, sustainable management of natural resources and climate actions and balanced territorial development.

Even if agriculture and agricultural policy enjoy an established role in rural development (e.g. Thomson et al. 2011), the empirical evidence of the impacts is mixed. In one extreme, Midmore et al. (2010) and Drabenstott (2003) argued that using agriculture as a vehicle for increasing the rural population is both inefficient and inappropriate. In Finland, a partial transfer of agricultural subsidies to regional investments increased both regional GDP and employment (Hyytiä 2014). Barkley (1990), Petrick and Zier (2012), and Berlinschi et al. (2014) found that CAP had mixed or negative impacts on agricultural employment. In contrast, e.g. Mattas and Loizou (2017) argued that the CAP has had a key role in maintaining job opportunities in agri-food and rural systems, thus helping maintain a running economy during the recession in Greece. Rizov et al. (2018) also suggested positive net spillovers of CAP payments to non-farm employment in the UK, and Garrone et al. (2019) found that CAP subsidies reduced the outflow of workforce in agriculture even if the costs were substantial. Accordingly, European Parliament (2016) concluded that the importance of agriculture and food processing as rural employers markedly varies in EU regions. Martinho (2015) called for a shift from agricultural growth to rural 
development, such that regional economic base would become more diversified. A number of regional scientists have argued that the growth of a region depends on the growth of its export industries (e.g., Richardson 1976). Rodríguez-Pose and Gill (2006) compared the changes in exports of agricultural industry with the exports of other manufacturing within eight major world economies. They found that regional instability increased when agricultural exports became less important than manufacturing exports. On the contrary, Kilkenny and Partridge (2009) argued that operations that could relax supply-side constraints and boost service sector activity would enhance rural development more efficiently than exports-based development policies. Cruz's et al. (2017) study suggested a relatively low effectiveness of the development strategy based on agricultural exports, as the more developed region might attract a significant part of the benefits.

This study investigates the impacts of the Russian food import ban on agriculture and food sectors and regional development in two Finnish rural regions when the major portion of food exports to Russia is cut down, with no compensation being offered to agricultural and food sectors. On the contrary, free capital and labour movements are enabled in the long run. This implies that the regional economy has time to find a new economic equilibrium, as capital and the labour force can move freely between various industries, while seeking higher profits and wages.

\section{Russian food import ban}

In 2014, the EU, USA and several other western countries imposed economic sanctions on Russia due to the Crimean and East Ukraine conflict. First-phase sanctions targeted to specific individuals, banks and companies in close relations with Russian President Putin. These sanctions froze assets and restricted foreign transactions. In addition, oil extraction and military equipment trading were restricted (Khachaturyan and Peterson 2017). In response, the Russian government banned the importation of agricultural and food products from these countries. The EU countries, as a block, were the largest foreign supplier of agricultural and food products to Russia in 2013. Seventy-three per cent of the banned imports originate in the EU (European Parliament 2014). Accordingly, the sanctions created major short- and medium-term challenges for the agricultural and food industries, impacting production, distribution and consumption (Liefert and Liefert 2015).

Due to their common border and shared history, Finland and Russia have long-term trade relations. Energy, crude oil, gas and minerals are the most important Russian exports to Finland (Finnish Customs 2018). Russia has been an important destination for Finnish products, including food products. Before its EU membership, Finland, with the help of export subsidies, transported milk and butter surpluses to Russia. Russia has remained an important destination for Finnish dairy exports during Finland's EU membership and a target for investments by the Finnish food industry and grocery businesses. Consequently, Finnish food trade faced a severe setback due to the Russian food import ban. Before the Ukrainian crisis, one third of Finnish agricultural and food exports were destined for Russia. In 2015, the share fell to 8.6 per cent. During 2011-2013, Finnish food exports to Russia were worth 270 million euros per year, constituting five per cent of the total Finnish exports to Russia. Milk and meat products were the most important commodities (Berg-Andersson and Kotilainen 2016).

Several papers have assessed the economic impacts of the Russian embargo on agricultural and food exports from the EU. Regional impacts of the ban, however, have not been studied. The studies cover both the exporting countries hit by the ban and the impacts on Russia itself. Wysokinski and Baran (2014), for example, reported the values and shares of the food and agricultural product exports from the EU to Russia before and after imposition of the embargo. Smutka et al. (2016) analysed the most affected product groups and products in terms of the food self-sufficiency ratio and import dependency ratio in various EU countries. Their results indicated that the ban definitely affected individual industries and individual countries of the EU. EU-level impacts, however, were moderate. Kutlina-Dimitrova (2015) focused on bilateral and total exports, production and welfare. The results showed only limited impacts on the exports. Accordingly, European companies succeeded in redirecting part of the banned exports to third countries and other Member States. Boulanger et al. (2016) concluded that Russia itself faces the greatest 
welfare losses. The ban hit the dairy, fruit and vegetable sectors most strongly in the EU, with Lithuania, Finland and Poland facing the greatest export decreases.

\section{South Ostrobothnia and North Karelia}

Two study regions represent different development paths of rural regions in Finland (Fig. 1). This paper explores whether the trade shock has different effects on the regions due to their different economic structures. Dependency on primary industries and Gross Domestic Products (GDP measures the output produced by factors of production located in the domestic economy) below the national average characterizes both study areas. The distinct features, however, are more prominent than the similarities. South Ostrobothnia, located in western Finland, is the country's main agricultural and food production region. Fifteen per cent of the employed work in agriculture and food production (Niemi and Väre, 2018).

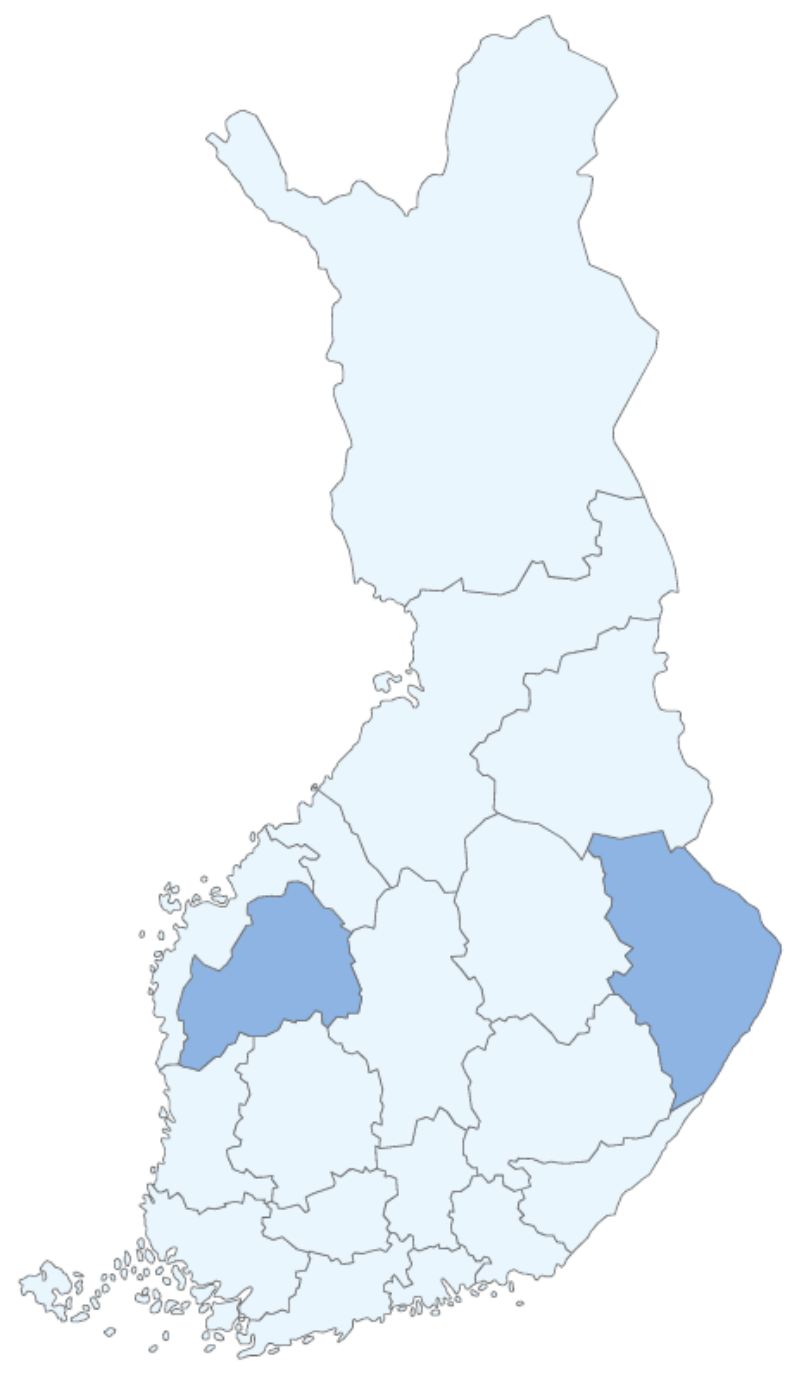

Fig 1. Locations of South Ostrobothnia and North Karelia in Finland.

In addition, a strong cluster of industries and services connected to agriculture are located in the area. In contrast, forestry and the wood and paper industries are among the key industries in North Karelia. Interestingly, North Karelia shares a common border with Russia and has active trade, tourism and co-operation connections with the country. For example, North Karelia and Russian Karelia co-operate in EU NordRegio projects. North Karelia has long battled against population loss and a high unemployment rate. Both the population and economic activities are concentrated in the urban centre of Joensuu, and remote areas have continued declining. Regional agencies have singled out Russian trade as one of the future opportunities for reversing 
this development. On the contrary, both economic activities and population are more evenly distributed in South Ostrobothnia. In addition, the region has caught up with national average GDP, has a low unemployment rate and has overcome the previous depopulation trend ${ }^{2}$ (Figure 2, 3). Figures 4 and 5 below present regional value added per capita and unemployment rates compared with national figures.

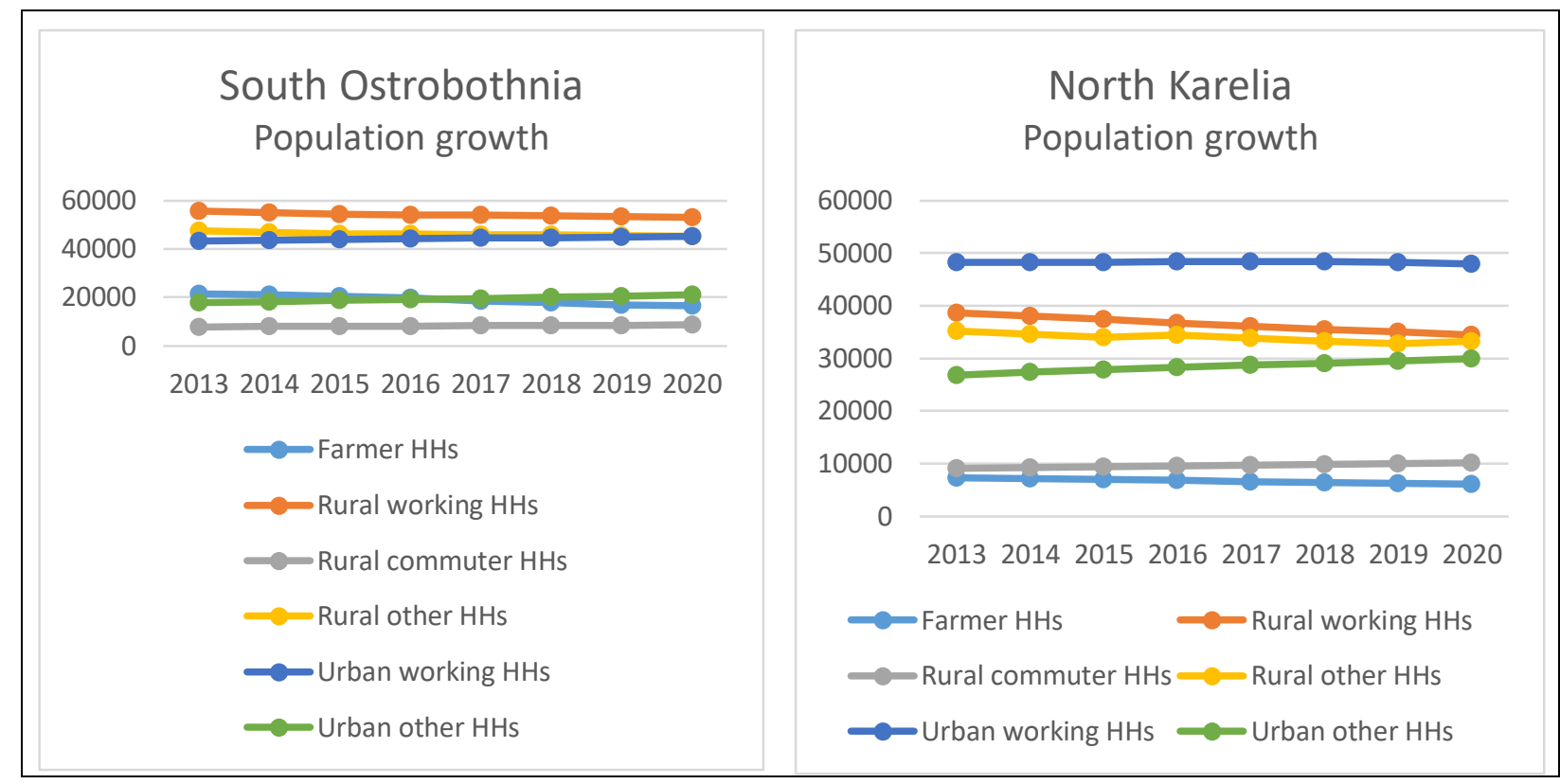

Fig 2. The base line population growth predictions in South Ostrobothnia.

Fig 3. The base line population growth predictions in North Karelia.

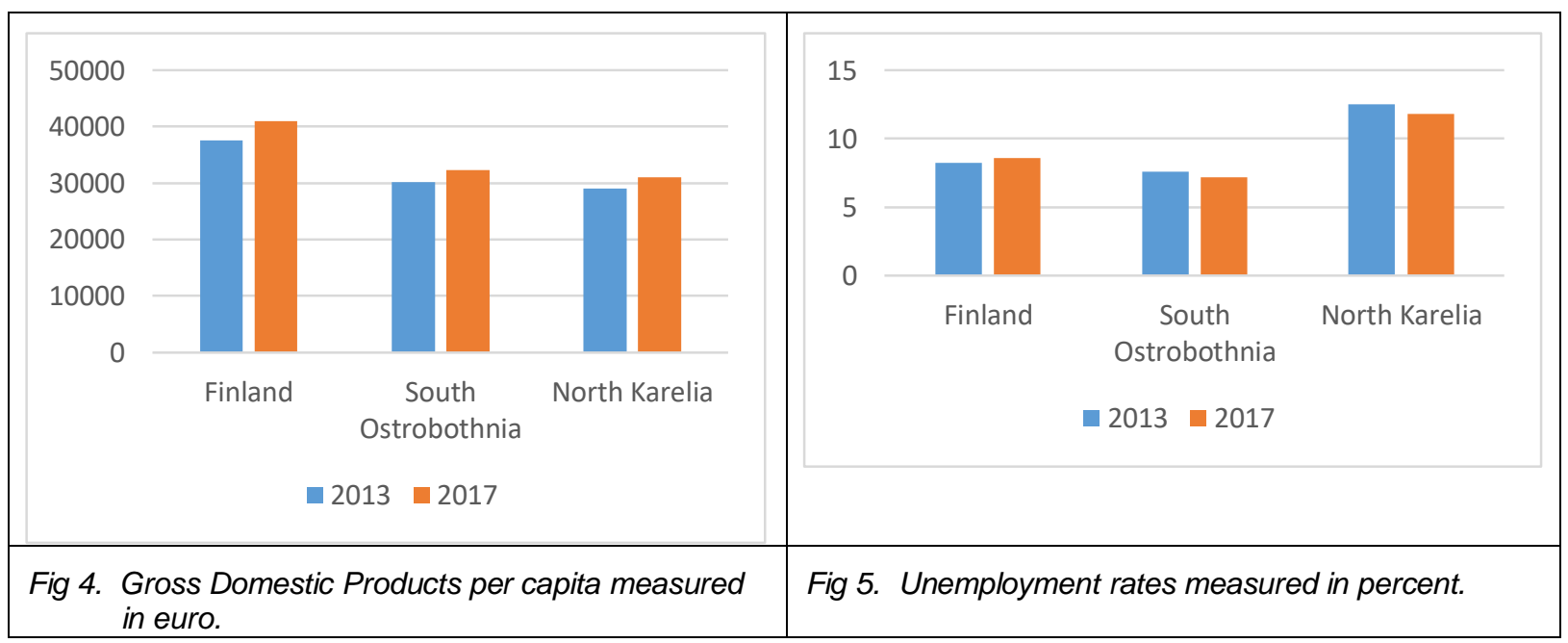

\section{Data and Methodology}

The study reports and analyses region-specific, rural-urban -separated data on regional economies, industries, employees and households. The data was arranged in social accounting matrices (SAM) that serve as base year data for the recursive dynamic general equilibrium model. SAM is an accounting framework that captures transactions and transfers between economic agents, such as industries, households and government, taking place during an accounting period (typically one year). It aims at portraying all the economic activities of a system: consumption, production, accumulation and distribution. SAM accounts are represented as a square matrix,

\footnotetext{
${ }^{2}$ Population forecasts by household groups related to base line scenarios and a map of Finland where the study regions are highlighted are presented in the Figures 2 and 3.
} 
where the incomes and receipts for each account are shown on a corresponding row and column of the matrix. (Round 2003)

The base regional input-output tables ${ }^{3}$ and trade flows were drawn from information collected and combined by the Finnish Government Institute for Economic Research (VATT). The base year used to compile VATT tables was 2008, which is when the most recent input-output tables were available for individual regions. The derivation of the VATT regional tables followed the construction of the TERM model database (Horridge 2011). To conclude, Finnish national input-output tables were the starting point. The gravity formula, implying that trade volumes follow an inverse power of distance, was used to construct trade matrices consistent with predetermined row and column totals. Considering Statistics Finland collects and compiles region specific data, for example, industries' cost structures of the VATT regional tables were region specific. Since the base year of this Russian embargo research is 2013, before the Russian embargo came into force, the final SAMs of this research are a combination of the VATT data and updated and additional regional information. The input-output tables of VATT from 2008 are not a major drawback in terms of regional GDP levels, as an economic recession after 2008 lowered Finnish GDP so that the 2008 GDP level was not reached until 2019 (Bank of Finland 2017). Despite minor inaccuracies in the division of the GDP among regional industries between 2008 and 2013, the same industries remained important.

Industry-specific value added changes from 2008 until 2013 were updated with actual 2013/2014 figures for the GDP growth projections. Growth forecasts were drawn from industry-specific national figures from 2015 to 2020 (ETLA 2016). Additional information on the regional economies and their rural and urban parts for 2013/2014 was collected from several databases. The division of industries into rural and urban was based on employment statistics along with information from industries and municipalities and on enterprise structures in 2013 and 2014 (Statistics Finland). Labour was divided into rural and urban low-skilled (blue collar) and high-skilled (white collar) labour. In addition, farming and other farm-related activities were separated into its own category. Correspondingly, the shares of the various household types were based on statistics of household dwelling units, household income and expenditures, employment by age and by regions (Statistics Finland) and survey information. The division into rural and urban was based on municipality information from 2014 (Statistics Finland). Finally, the SAMS were balanced using the cross entropy method (Robinson et al. 2000).

\subsection{CGE model}

Computable general equilibrium models (CGE) combine the abstract general equilibrium structure with realistic economic data. The models are comprised of a set of linear and nonlinear simultaneous equations that determine the behaviour of the economic agents in the model. They solve numerically for the levels of supply, demand and price supporting equilibrium across a specified set of markets. The CGE models are grounded in neoclassical economic theory. They are widely used to analyse the effects of policy shifts and external shocks that have structural, long run impacts on society (Wing 2004).

A recursive dynamic computable general equilibrium (CGE) model (Thurlow 2004) was used in the empirical analysis. The model is an extension of the IFPRI (International Food Policy Research Institute) static model (Lofgren et al. 2002) and is open code. Recursive dynamic implies that the behaviour of the agents is based on adaptive expectations as opposed to the forward-looking expectations that underlie inter-temporal dynamic models. This type of model requires within-period and between-period specifications. The key model features relevant to this study are outlined below by following Thurlow (2004).

The within-period, i.e. static model, specifies factor (labour, land and capital) and goods markets. It replicates the base year data specified in the SAM. Each activity represents the behaviour of a profit-maximising producer. The profits are maximised subject to the two-layered production

\footnotetext{
3 The input-output tables formed from the supply and use tables examine the use of the outputs of industries as intermediate product inputs and for final use in other industries. Thus, the input-output tables provide a picture of the structure of production activity and the interdependencies between industries (Statistics Finland).
} 
technology. Activities pay activity-specific wages and rents to households and firms. Consumer preferences are represented by a linear expenditure system (LES) of demand. Each sector earns specific returns through capital. Low-skilled labour, farmers and other farm work labour supplies are assumed to be perfectly elastic at a given real wage. Skilled labour faces an upward-sloping labour supply curve, with wage elasticities determining supply adjustments following changes in real wages. Fixed shares of investment goods determine the disaggregation of investment into demand for final commodities. Savings are collected into a savings pool from which investments are financed. Substitution possibilities exist between production for domestic and foreign markets. This decision by producers is governed by a constant elasticity of transformation (CET) function, which distinguishes between exported and domestic goods, and thus captures any time or quality differences between the two products.

Between-period specification: The static model is extended to a recursive dynamic model in which selected parameters are updated based on the modelling of inter-temporal behaviour and results from previous periods. Current economic conditions, such as capital availability, are thus endogenously dependent on past outcomes. The dynamic model is also exogenously updated to reflect demographic and technological changes. The process of capital accumulation is modelled endogenously, with previous-period investment generating new capital stock for the subsequent period. Although the allocation of new capital across sectors is influenced by each sector's initial share of aggregate capital income, the final sectoral allocation of capital in the current period is dependent on the capital depreciation rate and on sectoral profit-rate differentials from the previous period. Sectors with above-average capital returns receive a larger share of investible funds than their share in capital income. The skilled labour supply adjusts endogenously across periods in response to continuing changes in real wages. This treatment of the model's labour supply dynamics assumes that the skilled labour category involves neither a binding supply-constraint nor involuntary unemployment.

\subsection{Macroeconomic closures and elasticity parameters}

Model closures determine how the linkages of the macroeconomic system are specified and how various institutions operate. The choice of the closures should be based on empirical analysis of the economy (Harrigan and McGregor 1989, Julia-Wise et al. 2002). The model includes three macroeconomic balances: external balance, i.e. the current account of the balance of the payments (including the trade balance) saving-investment balance and government balance. The choices of different macroeconomic balances typically influence the results of simulations, but leave the base year solution unchanged.

For external balance, the real exchange rate is flexible while foreign savings (the current account deficit) are fixed. Import value adjusts to the export value to retain outer balance. This approach is reasonable, especially when modelling the whole country's foreign trade. The first set of Russian embargo simulations was run under this external closure (Basic1/Russia1). Regional trade and investments, however, bear specific characteristics. In this research, the majority of the trade flows and foreign savings originate from the rest of Finland, not from foreign nations. Therefore, flexible foreign savings and a fixed exchange rate (Basic2/Russia2) may better portray the situation of a small and open regional economy dependent on national trade, transfers and investments. This approach enables long-term capital movements between industries, as it loosens rigidities of the available investment funds.

In Finland, taxation is decided upon at either a national or a municipal level, not at a regional level. The chosen government closure leaves all tax rates fixed but enables changes in government savings. The investments are savings driven. The production elasticities, except for the output aggregation elasticity drawn from the model's default, are based on previous Finnish research (Törmä and Rutherford 1992, Vaittinen 2004), and the household income elasticities are based on information from the US Economic Research Service.

A number of previous studies (see Bilgic et al. 2002) suggest that substitution elasticities for regional trade should be higher than those applied in international trade studies. Regions face lower barriers to trade, as they are geographically closer to each other (Partridge and Rickman 
1998). However, Bilgic et al. (2002) did not find evidence to support this hypothesis. In effect, they suggest applying parameter values from 0.45 to 2.80 instead of the commonly used range from 2.00 to 3.50 . We apply a value of 2.00 for all the products in our study. In Finland, Törmä and Lehtonen (2009) applied a value of 4.00 for both Armington and transformation elasticity, and Vaittinen (2004) a value as high as 8.00. To test the effects of trade elasticities, we applied a value of 10.00 for agricultural and food products during the sensitivity analysis. Given substitution elasticities and the expenditure shares from SAM, the CES parameters can be solved to reproduce the benchmark year data.

\subsection{Simulations}

To simulate the Russia food import ban, the tariff rates were set at a level that cuts down the exports of agricultural and food products to Russia by approximately $95 \%$. This approach follows Kutlina-Dimitrova (2015), who argues that an import ban is simply a quota with zero (or close to zero) trade value associated with it. The model was calibrated to replicate projected sectoral growth rates for the period 2013-2020 (ETLA 2016). The data on imports, exports and import tariffs concern year 2013 (Finnish Customs 2016, WTO). The model was solved for the period 2013-2020.

Table 1 shows the most important exports and all the agricultural and food product exports. Exports are separated by destination: the rest of Finland (ROF), European Union (EU), Russia and the rest of the world (ROW). Food products to all destinations are the most important exports for South Ostrobothnia (25\% of all exports), while exports from North Karelia focus on forestryrelated products $(19 \%)$ and electronic equipment $(14 \%)$, with minerals being equally important exports as food products (6\%).

Tab 1. Regional exports in the base year, millions of euros.

\begin{tabular}{|l|c|c|c|c|c|c|c|c|}
\hline & \multicolumn{3}{|c|}{ South Ostrobothnia } & \multicolumn{4}{c|}{ North Karelia } \\
\hline & ROF & EU & Russia & ROW & ROF & EU & Russia & ROW \\
\hline Agricultural & 168.7 & 4.6 & 1.0 & 12.2 & 49.5 & 3.3 & 0.7 & 8.8 \\
\hline Food & 711.3 & 90.0 & 53.6 & 36.2 & 92.8 & 16.4 & 9.8 & 6.6 \\
\hline Metal & 502.9 & 79.8 & 8.1 & 37.0 & 31.8 & 265.2 & 26.0 & 177.4 \\
\hline Wood / Paper & 169.0 & 69.4 & 6.8 & 46.4 & 96.2 & 122.8 & 31.0 & 165.2 \\
\hline Electronics & 177.5 & 64.3 & 16.2 & 86.4 & 60.6 & 5.0 & 30.4 & 7.2 \\
\hline
\end{tabular}




\section{Results}

The results are divided into two sections. The first section outlines the economic structures in the base year SAMs and the baseline growth projections of regional industries modelled with the CGE model. Agriculture (the classification of farms can be found in the Fig. 6) and food industries and region-specific key industries are particularly scrutinised. The second section displays the results of the Russian food import ban simulations.

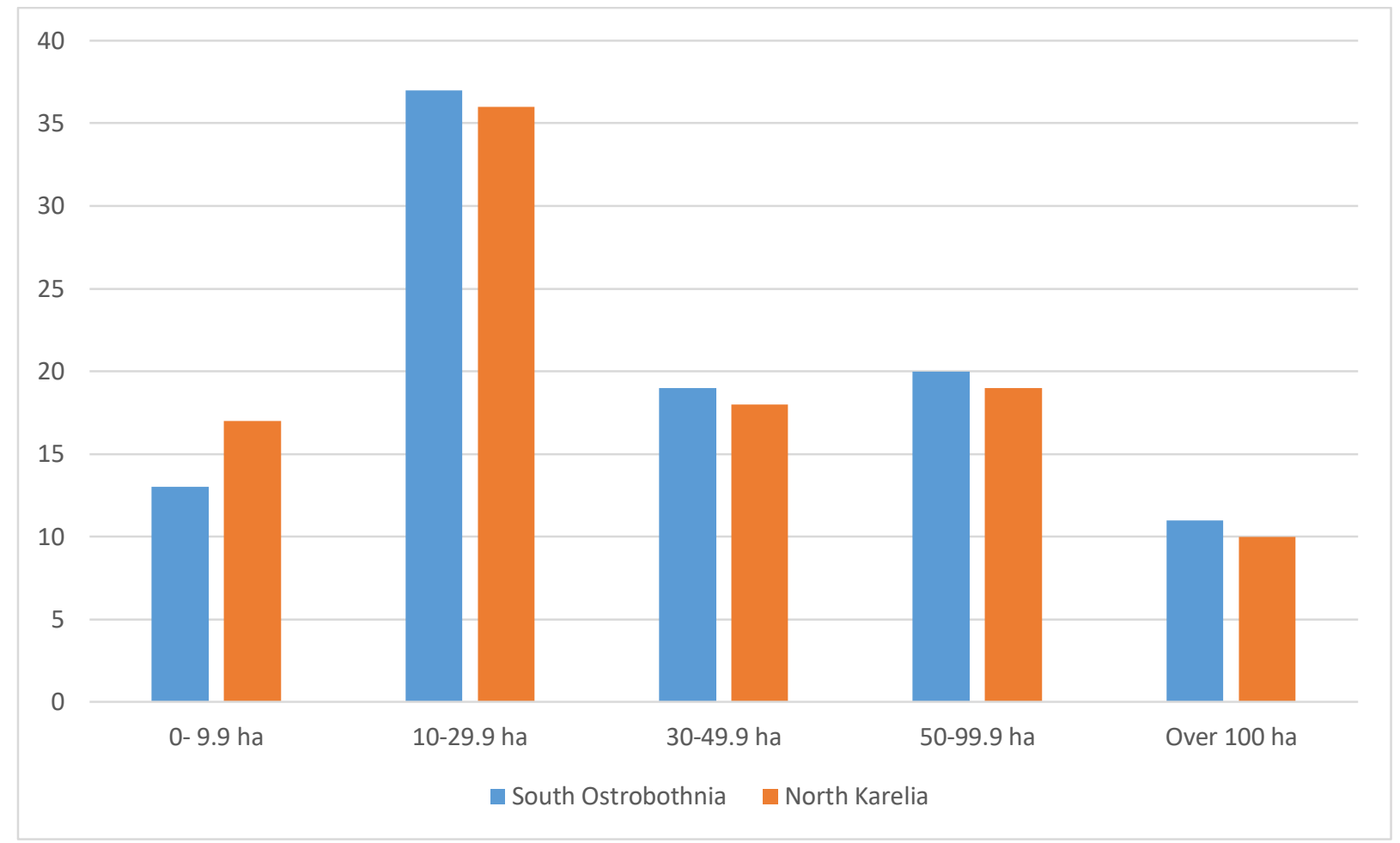

Fig 6. Farms classified by land area categories.

Table 2 separates the rural and urban work force by education level. The most important industries in addition to the agriculture and food industries are included. Skilled labour corresponds to white-collar employees, while unskilled labour denotes blue-collar employees. 'Other farm activities' represent farmers' work input allocated to other than actual agriculture.

The different weights of the rural and urban areas are evident. In South Ostrobothnia, $61 \%$ of wages were paid by rural industries, while the corresponding share for North Karelia was $45 \%$. In North Karelia, urban industries exceeded rural ones except for agriculture. On the contrary, employment in rural industries exceeded each of the corresponding urban industries in South Ostrobothnia. The food industry paid only $1.2 \%$ of the regional wages in North Karelia, opposed to $4.4 \%$ in South Ostrobothnia. Wood and paper manufacturing was among the top industries in North Karelia. Services accounted for $58 \%$ of the wages in rural South Ostrobothnia, and $60 \%$ in North Karelia. The corresponding shares in urban areas were $71 \%$ and $72 \%$, respectively. 
Tab 2. Most important industries and rural-urban employment.

\begin{tabular}{|c|c|c|c|c|c|c|c|c|}
\hline & \multicolumn{4}{|c|}{$\begin{array}{l}\text { South Ostrobothnia, wages million } \\
\text { EUR }\end{array}$} & & & & \multirow[b]{3}{*}{\begin{tabular}{|l|} 
Urban \\
Total \\
\end{tabular}} \\
\hline & \multicolumn{2}{|c|}{ Rural employment } & \multirow[b]{2}{*}{ Farmers } & \multirow[b]{2}{*}{$\begin{array}{l}\text { Farm } \\
\text { other }\end{array}$} & \multirow[b]{2}{*}{\begin{tabular}{|l|} 
Rural \\
Total \\
\end{tabular}} & \multicolumn{2}{|c|}{ Urban employment } & \\
\hline & Skilled & Unskilled & & & & Skilled & Unskilled & \\
\hline Agriculture & 46.04 & 260.88 & 2268.90 & 0.00 & 2575.82 & 6.04 & 34.24 & 40.28 \\
\hline Food & 571.66 & 1490.60 & 0.00 & 3.82 & 2066.08 & 275.27 & 717.75 & 993.02 \\
\hline Metal & 1313.31 & 3160.19 & 0.00 & 2.23 & \begin{tabular}{|l|l|}
445.73 \\
\end{tabular} & 632.38 & 1521.69 & 2154.07 \\
\hline Construction & 521.70 & 2347.64 & 0.00 & 6.54 & 2875.88 & 363.33 & 1634.99 & 1998.32 \\
\hline Distribution & 1031.84 & 3658.35 & 0.00 & 10.61 & 4700.81 & 811.36 & 2876.63 & 3687.99 \\
\hline Transportation & 264.53 & 1498.98 & 0.00 & 1.77 & 1765.27 & 203.04 & 1150.59 & 1353.63 \\
\hline $\begin{array}{l}\text { Technical } \\
\text { services }\end{array}$ & 814.33 & 995.29 & 0.00 & 31.23 & 1840.85 & 736.54 & 900.21 & 1636.75 \\
\hline Health services & 2741.64 & 3786.07 & 0.00 & 2.86 & 6530.57 & 2293.76 & 3167.57 & 5461.33 \\
\hline \multirow[t]{4}{*}{ TOTAL of all } & 13609.20 & 26461.32 & 2268.90 & 242.99 & \begin{tabular}{|l|l|}
42582.41 \\
\end{tabular} & 9286.67 & 17527.92 & 26814.59 \\
\hline & \multicolumn{4}{|c|}{ North Karelia, wages million EUR } & & & & \\
\hline & \multicolumn{2}{|c|}{ Rural employment } & & & & \multicolumn{2}{|c|}{ Urban employment } & \\
\hline & Skilled & Unskilled & Farmers & $\begin{array}{l}\text { Farm } \\
\text { other }\end{array}$ & $\begin{array}{l}\text { Rural } \\
\text { Total }\end{array}$ & Skilled & Unskilled & $\begin{array}{l}\text { Urban } \\
\text { Total }\end{array}$ \\
\hline Agriculture & 22.57 & 127.91 & 1183.24 & 0.00 & 1333.72 & 4.59 & 25.99 & 30.58 \\
\hline Food & 95.93 & 250.13 & 0.00 & 0.94 & 347.00 & 98.79 & 257.60 & 356.40 \\
\hline Wood\&Paper & 249.51 & 998.04 & 0.00 & 2.25 & 1249.80 & 256.96 & 1027.84 & 1284.80 \\
\hline Metal & 532.86 & 1282.20 & 0.00 & 1.30 & 1816.36 & 548.76 & 1320.48 & 1869.24 \\
\hline Construction & 358.12 & 1611.53 & 0.00 & 6.92 & 1976.57 & 474.99 & 2137.44 & 2612.43 \\
\hline Distribution & 491.03 & 1740.92 & 0.00 & 7.62 & 2239.57 & 841.57 & 2983.76 & 3825.33 \\
\hline $\begin{array}{l}\text { Technical } \\
\text { services }\end{array}$ & 468.01 & 572.02 & 0.00 & 22.79 & 1062.82 & 951.34 & 1162.75 & 2114.08 \\
\hline Health services & 1948.41 & 2690.66 & 0.00 & 2.39 & 4641.46 & \begin{tabular}{|l|}
2246.60 \\
\end{tabular} & 3102.44 & 5349.04 \\
\hline TOTAL of all & 8324.33 & 15767.28 & 1183.24 & 312.26 & 25587.12 & 11379.54 & 19835.94 & 31215.48 \\
\hline
\end{tabular}

\subsection{Industries and growth projections}

Gross Domestic Product growth projections are based on ETLA's (2016) industry-specific national forecasts for the period 2015-2020. These baseline projections follow the moderate growth path, in which foreign savings are fixed and investment funds are therefore only available from local sources (Basic1 simulation). As for the general economic structures of the study areas, manufacturing and private services were the largest aggregate industries in South Ostrobothnia, while private services were clearly the most important in North Karelia. If public services were also taken into account, services accounted for a lion share of the GDP. Figures 3 and 4 further detail the regional economies. TEC combines the whole 'technology industry', i.e. the metal industry and vehicle and electronic equipment production. The economic downfall after $2008^{4}$ is visible in the figures. The GDPs of the technology industries turned down and could not overtake their original levels during the projection period. In South Ostrobothnia, agriculture passed technology industries in 2014. Moreover, food manufacturing accounted for a prominent share of the regional GDP.

In the base year, the leading industries in North Karelia were construction, the technology industry and combined forestry and mining. After the economic downfall, forestry and mining compensated the losses of manufacturing. Opposed to South Ostrobothnia, food manufacturing was not among

\footnotetext{
${ }^{4}$ Please see the discussion on the VATT input output tables in the paragraph "Data and methodology".
} 
the top industries, as for example wood and paper, and chemicals and plastics had greater shares.

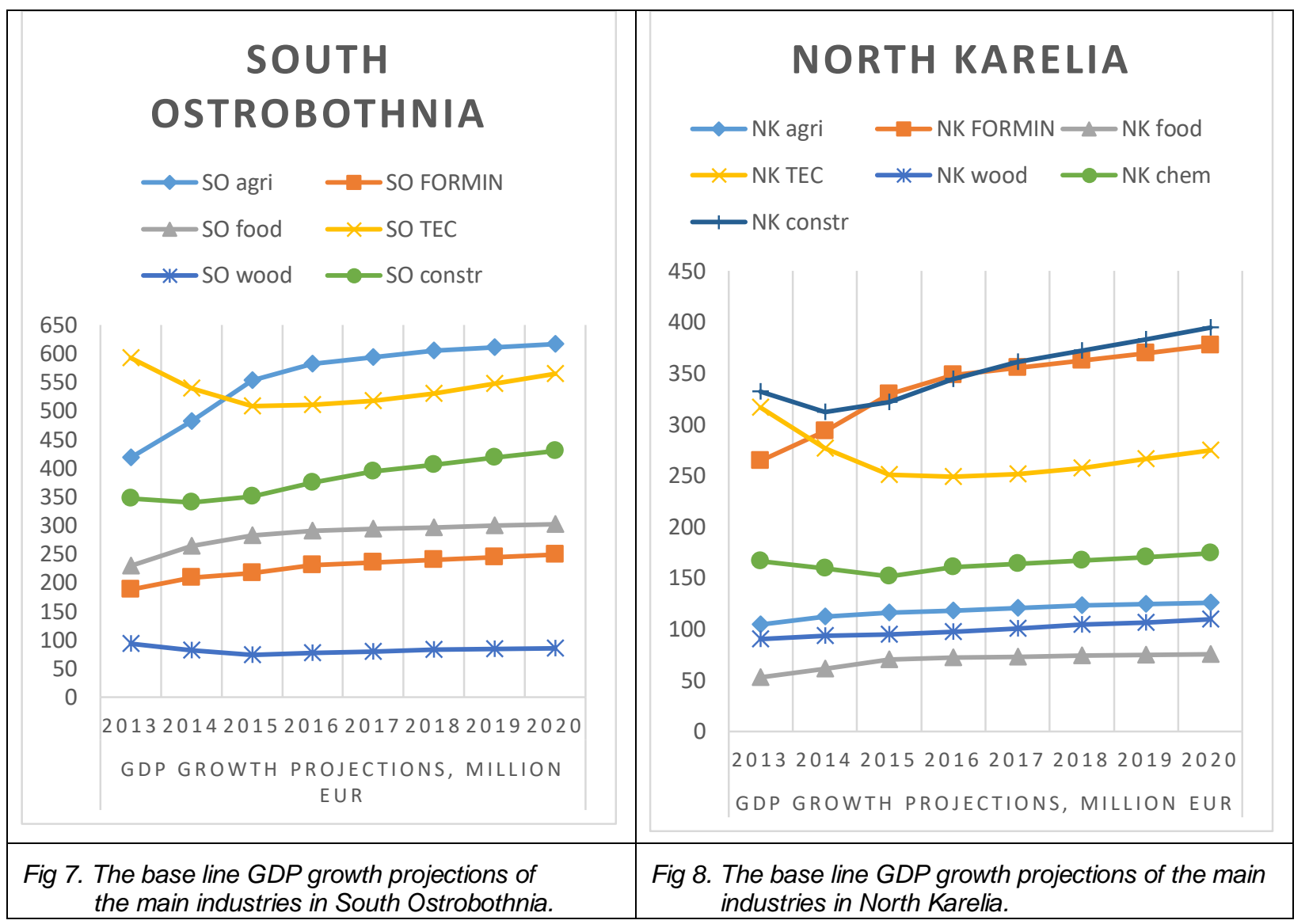

\subsection{Russian embargo}

Below, the impacts of the Russian import embargo are compared with values from the baseline projections. The first set of simulations was run under the assumption of fixed foreign savings and a flexible exchange rate (Basic1/Russia1). To reflect the situation of a small and open regional economy, the foreign savings were set flexible and the exchange rate fixed in the second set of simulations (Basic2/Russia2). Table 3 presents the macroeconomic indicators. The columns give the \% change in the base values, with the exception of the \% difference columns which give the $\%$ point difference between the projections for the baseline and Russian ban simulations.

When the exchange rate was flexible (Russia1), the indicators for both regions showed negative effects compared with the Basic1 projection, but the effects were larger in South Ostrobothnia. For example, regional GDP $(-0.47 \%)$ and total exports $(-2.23 \%)$ and investments $(-1.44 \%)$ decreased more in South Ostrobothnia. Flexible foreign savings (Russia2) produced opposite results. All indicators in North Karelia showed negative changes, while changes in South Ostrobothnia were positive, especially in terms of investments (33.69\%), total absorption (9.34\%) and regional GDP (3.51\%). 
Tab 3. Comparison of the demand-side GDP effects, \% changes.

\begin{tabular}{|l|c|c|c|c|c|c|c|}
\hline & \multicolumn{2}{l|}{$\begin{array}{l}\text { South } \\
\text { Ostrobothnia }\end{array}$} & & & & & \\
\hline & BASE M€ & Basic1 & Russia1 & Difference1\% & Basic2 & Russia2 & Difference2\% \\
\hline $\begin{array}{l}\text { Private } \\
\text { consumption }\end{array}$ & 3138 & 16.70 & 15.90 & -0.80 & 18.51 & 21.58 & 3.07 \\
\hline Investments & 1238 & 28.34 & 26.90 & -1.44 & 54.82 & 88.51 & 33.69 \\
\hline Exports & 4301 & 16.15 & 13.92 & -2.23 & 14.02 & 13.44 & -0.58 \\
\hline Imports & 4417 & 15.73 & 13.49 & -2.24 & 21.58 & 27.66 & 6.07 \\
\hline $\begin{array}{l}\text { GDP at market } \\
\text { prices }\end{array}$ & 5378 & 17.58 & 16.83 & -0.74 & 18.22 & 22.31 & 4.09 \\
\hline $\begin{array}{l}\text { GDP at factor } \\
\text { costs }\end{array}$ & 4780 & 19.64 & 19.17 & -0.47 & 19.64 & 23.15 & 3.51 \\
\hline & North Karelia & & & & & \\
\hline & BASE M€ & Basic1 & Russia1 & Difference1\% & Basic2 & Russia2 & Difference2\% \\
\hline $\begin{array}{l}\text { Private } \\
\text { consumption }\end{array}$ & 2598 & 16.33 & 16.02 & -0.31 & 25.08 & 24.53 & -0.54 \\
\hline Investments & 783 & 41.49 & 40.59 & -0.90 & 144.62 & 140.37 & -4.25 \\
\hline Exports & 3057 & 15.22 & 14.54 & -0.68 & 6.16 & 5.72 & -0.44 \\
\hline Imports & 3161 & 14.72 & 14.04 & -0.68 & 41.31 & 39.79 & -1.52 \\
\hline $\begin{array}{l}\text { GDP at market } \\
\text { prices }\end{array}$ & 4168 & 19.70 & 19.36 & -0.35 & 17.72 & 17.42 & -0.31 \\
\hline $\begin{array}{l}\text { GDP at factor } \\
\text { costs }\end{array}$ & 3680 & 21.01 & 20.71 & -0.30 & 21.01 & 20.67 & -0.34 \\
\hline
\end{tabular}

Table 4 distinguishes activity-specific impacts of the shocks. As a result of Russia1 simulations, the agriculture and food industries were hit the hardest, with agriculture losing $5.8 \%$ in South Ostrobothnia and $4.2 \%$ in North Karelia of the potential growth from the base line (Basic) values. The corresponding fall of the value added of the food industries was $12.4 \%$. On the contrary, import ban increased the value added of forestry, the timber and paper industries, and the metal industry, which compete for capital and labour with agriculture and the food industry. Industries clearly connected to or dependent on the agriculture and food industries were among the losers. Accordingly, value added and domestic activities and sales declined for distribution and transportation, and hotels and restaurants.

The two regions reacted differently when foreign savings were flexible and the exchange rate was fixed (Russia2). In South Ostrobothnia, the trade shock moved the economic focus towards industries that could benefit from the 'foreign' capital. Metal $(+4.46 \%)$ and electronics particularly gained due to the ban. In general, private services gained and imports compensated the losses of distribution. The aggregate value added by the secondary and tertiary sectors increased by $6 \%$ and $3 \%$, respectively. Even agriculture, to some extent, was able to catch the positive development by utilising the additional capital made available. By contrast, other industries in North Karelia were unable to compensate for the losses from agriculture and the food industry. Moreover, the value added of agriculture and the food industry fell even more compared to the Russia1 simulation.

As a result of the flexible foreign savings, South Ostrobothnia took advantage of the increased investment funds, enabling domestic activities, e.g. construction and technical services, to take a clear upward turn. Corresponding development was not observed in North Karelia.

Table 5 shows the \%-changes in factor incomes. Again, the effects were larger in South Ostrobothnia. As a result of Russia1 compared with Basic1, capital and land incomes decreased in both regions. Labour incomes decreased in all groups, excluding 'other farm activities'. Capital and land incomes generally grew during the projection period (Basic). As a result of Russia1, unskilled labour experienced greater wage decreases than skilled labour, and the wages of urban workers decreased more than those of rural workers. Competition for employment in the other 
sectors increased when the work force from agriculture and the food industry sought optional employment.

Tab 4. Activity-specific \% changes in value added.

\begin{tabular}{|c|c|c|c|c|c|c|}
\hline & \multicolumn{3}{|c|}{ South Ostrobothnia } & \multirow[b]{2}{*}{ Difference1\% } & \multirow[b]{2}{*}{ Russia2 } & \multirow[b]{2}{*}{ Difference2\% } \\
\hline & BASE ME & Basic & Russia1 & & & \\
\hline \multicolumn{7}{|l|}{ Value added } \\
\hline Agriculture & 419 & 47.38 & 41.53 & -5.84 & 43.26 & -4.12 \\
\hline Food industry & 229 & 31.89 & 19.49 & -12.40 & 19.58 & -12.31 \\
\hline Forestry & 151 & 37.24 & 42.31 & 5.07 & 43.06 & 5.82 \\
\hline Wood and paper & 94 & -8.24 & -5.65 & 2.59 & -4.55 & 3.69 \\
\hline Metal & 323 & -9.21 & -6.84 & 2.37 & -4.75 & 4.46 \\
\hline Technical services & 157 & 59.60 & 61.51 & 1.91 & 65.60 & 6.00 \\
\hline Health services & 533 & 17.86 & 18.25 & 0.39 & 17.85 & -0.02 \\
\hline Distribution & 414 & 13.57 & 12.34 & -1.23 & 17.39 & 3.82 \\
\hline Transportation & 247 & 1.96 & 1.44 & -0.52 & 2.29 & 0.34 \\
\hline \multirow[t]{3}{*}{ Hotels and restaurants } & 55 & 35.79 & 35.09 & -0.71 & 38.71 & 2.92 \\
\hline & \multicolumn{2}{|c|}{ North Karelia } & & & & \\
\hline & BASE M€ & Basic & Russia1 & Difference1\% & Russia2 & Difference2\% \\
\hline \multicolumn{7}{|l|}{ Value added } \\
\hline Agriculture & 104 & 20.42 & 16.25 & -4.18 & 15.03 & -5.39 \\
\hline Food industry & 53 & 42.98 & 30.61 & -12.37 & 29.86 & -13.12 \\
\hline Forestry & 226 & 50.31 & 51.16 & 0.86 & 51.43 & 1.12 \\
\hline Wood and paper & 90 & 21.76 & 22.54 & 0.78 & 23.16 & 1.40 \\
\hline Metal & 135 & -5.89 & -5.60 & 0.30 & -5.35 & 0.54 \\
\hline Technical services & 153 & 41.26 & 41.25 & 0.00 & 41.61 & 0.35 \\
\hline Health services & 422 & 30.25 & 30.29 & 0.04 & 30.42 & 0.18 \\
\hline Distribution & 279 & 28.63 & 27.77 & -0.87 & 27.49 & -1.14 \\
\hline Transportation & 152 & 6.67 & 6.54 & -0.14 & 6.81 & 0.14 \\
\hline Hotels and restaurants & 56 & 36.68 & 36.12 & -0.56 & 36.08 & -0.60 \\
\hline
\end{tabular}

Compared with Basic2, Russia2 simulation resulted in higher factor earnings for each labour, capital and land category, excluding farmers in South Ostrobothnia. In North Karelia, by contrast, 'other farm activities' and 'land rent' were the only gaining factor groups.

Tab 5. Factor incomes, \%-changes.

\begin{tabular}{|c|c|c|c|c|c|c|c|}
\hline & \multicolumn{3}{|c|}{ South Ostrobothnia } & \multirow[b]{2}{*}{ Difference1\% } & \multirow[b]{2}{*}{ Basic2 } & \multirow[b]{2}{*}{ Russia2 } & \multirow[b]{2}{*}{ Difference2\% } \\
\hline & BASE M€ & Basic1 & Russia1 & & & & \\
\hline Capital & 2059 & 6.14 & 4.56 & -1.58 & 4.92 & 7.38 & 2.46 \\
\hline Land & 140 & 75.05 & 73.45 & -1.60 & 80.70 & 81.90 & 1.21 \\
\hline \multicolumn{8}{|l|}{ Labour: } \\
\hline Rural skilled & 739 & 26.40 & 26.16 & -0.24 & 31.25 & 36.27 & 5.03 \\
\hline Urban skilled & 502 & 23.30 & 22.83 & -0.46 & 25.40 & 29.72 & 4.31 \\
\hline Farmers & 59 & 73.28 & 63.93 & -9.35 & 75.14 & 68.32 & -6.82 \\
\hline Other farm activities & 8 & 26.15 & 27.92 & 1.77 & 26.47 & 31.89 & 5.42 \\
\hline Rural unskilled & 770 & 24.21 & 23.26 & -0.95 & 28.97 & 34.64 & 5.67 \\
\hline Urban unskilled & 502 & 24.11 & 23.10 & -1.02 & 27.72 & 33.15 & 5.43 \\
\hline
\end{tabular}




\begin{tabular}{|l|c|c|c|c|c|c|c|}
\hline & \multicolumn{2}{|l|}{ North Karelia } & & & & & \\
\hline & BASE M€ & Basic1 & Russia1 & Difference1\% & Basic2 & Russia2 & Difference2\% \\
\hline Capital & 1533 & 8.41 & 7.69 & -0.72 & 13.11 & 12.05 & -1.07 \\
\hline Land & 129 & 91.28 & 90.93 & -0.35 & 88.67 & 88.70 & 0.03 \\
\hline Labour: & & & & & & & \\
\hline Rural skilled & 438 & 19.67 & 19.35 & -0.32 & 31.31 & 30.69 & -0.62 \\
\hline Urban skilled & 607 & 20.26 & 19.94 & -0.91 & 32.36 & 31.73 & -0.63 \\
\hline Farmers & 14 & 63.97 & 56.87 & -7.10 & 64.12 & 55.55 & -8.57 \\
\hline Other farm activities & 10 & 33.86 & 34.11 & 0.25 & 35.58 & 35.89 & 0.31 \\
\hline Rural unskilled & 426 & 29.67 & 29.07 & -0.60 & 50.07 & 48.99 & -1.07 \\
\hline Urban unskilled & 522 & 30.00 & 29.39 & -0.61 & 53.80 & 52.62 & -1.18 \\
\hline
\end{tabular}

Table 6 shows the changes in factor supply. During the projection period, employment and capital increased such that rural employment increased more in South Ostrobothnia, whereas urban employment increased more in North Karelia. When comparing Russia2 with Basic2, South Ostrobothnia turned the decrease in agricultural and food exports into a positive outcome for the whole region, in terms of employment, while the employment effects were negative in North Karelia except for 'other farm activities'.

Tab 6. Quantity of factor supply.

\begin{tabular}{|c|c|c|c|c|c|c|}
\hline & \multicolumn{3}{|c|}{ South Ostrobothnia } & \multirow[b]{2}{*}{ Basic2 } & \multirow[b]{2}{*}{ Russia2 } & \multirow[b]{2}{*}{ Difference2\% } \\
\hline & Basic1 & Russia1 & Difference1\% & & & \\
\hline Capital & 102.2 & 101.05 & -1.15 & 133.95 & 145.05 & 11.10 \\
\hline Labour & 11.01 & 10.61 & -0.4 & 18.25 & 21.30 & 3.05 \\
\hline Rural skilled & 10.39 & 10.82 & 0.43 & 18.57 & 21.67 & 3.10 \\
\hline Urban skilled & 6.17 & 5.97 & -0.2 & 8.80 & 10.37 & 1.57 \\
\hline Farmers & 51.34 & 43.99 & -7.35 & 58.22 & 50.29 & -7.93 \\
\hline $\begin{array}{l}\text { Other farm } \\
\text { activities }\end{array}$ & 10.18 & 12.36 & 2.18 & 14.25 & 17.76 & 3.51 \\
\hline Rural unskilled & 8.48 & 8.27 & -0.21 & 16.52 & 20.21 & 3.69 \\
\hline \multirow[t]{3}{*}{ Urban unskilled } & 6.88 & 6.19 & -0.69 & 10.81 & 13.29 & 2.48 \\
\hline & \multicolumn{2}{|c|}{ North Karelia } & & & & \\
\hline & Basic1 & Russia1 & Difference1\% & Basic2 & Russia2 & Difference2\% \\
\hline Capital & 96.13 & 95.69 & -0.44 & 171.07 & 170.17 & -0.90 \\
\hline Land & & & 0 & & & \\
\hline Labour & 12.65 & 12.3 & -0.35 & 28.88 & 28.29 & -0.59 \\
\hline Rural skilled & 6.16 & 6.07 & -0.09 & 16.53 & 16.33 & -0.20 \\
\hline Urban skilled & 6.82 & 6.72 & -0.1 & 16.74 & 16.54 & -0.20 \\
\hline Farmers & 45.47 & 39.42 & -6.05 & 45.64 & 38.45 & -7.19 \\
\hline $\begin{array}{l}\text { Other farm } \\
\text { activities }\end{array}$ & 18.91 & 19.34 & 0.43 & 19.58 & 20.21 & 0.63 \\
\hline Rural unskilled & 15.03 & 14.71 & -0.32 & 33.17 & 32.62 & -0.55 \\
\hline Urban unskilled & 15.48 & 15.14 & -0.34 & 35.66 & 35.02 & -0.64 \\
\hline
\end{tabular}

As for the household, the second set of simulations resulted in increased income for all South Ostrobothnian household groups contrary to decreased levels in North Karelia. Incomes of rural households additionally increased comparatively more in South Ostrobothnia. 
Producer and consumer price changes are presented in Tab. 7. As a result of the trade embargo, the export prices of agricultural and food products decreased as expected.

Tab 7. Price tables.

\begin{tabular}{|c|c|c|c|c|c|c|c|c|}
\hline & \multicolumn{8}{|c|}{ Producer price (average output price) ${ }^{5}$} \\
\hline & \multicolumn{4}{|c|}{ South Ostrobothnia } & \multicolumn{4}{|c|}{ North Karelia } \\
\hline & Basic1 & Change & Basic2 & Change & Basic1 & Change & Basic2 & Change \\
\hline \multirow{2}{*}{$\begin{array}{l}\text { Agricultural } \\
\text { Food products }\end{array}$} & - & - & - & - & + & - & + & - \\
\hline & - & - & - & - & + & - & - & - \\
\hline \multirow{6}{*}{$\begin{array}{l}\text { Forestry } \\
\text { Metal } \\
\text { Distribution }\end{array}$} & - & - & - & + & - & - & - & 0 \\
\hline & + & + & + & + & + & - & + & - \\
\hline & + & - & + & + & - & - & - & - \\
\hline & \multicolumn{8}{|c|}{ Consumer price (composite good) } \\
\hline & \multicolumn{4}{|c|}{ South Ostrobothnia } & \multicolumn{4}{|c|}{ North Karelia } \\
\hline & Basic1 & Change & Basic2 & Change & Basic1 & Change & Basic2 & Change \\
\hline Agricultural & - & - & - & - & + & - & + & - \\
\hline Food products & - & + & - & + & - & + & - & + \\
\hline Forestry & - & - & - & + & - & - & - & - \\
\hline Metal & + & + & + & + & + & - & + & - \\
\hline Distribution & + & - & + & + & - & - & - & - \\
\hline
\end{tabular}

\subsection{Sensitivity analysis}

For the sensitivity analysis, the trade elasticity values were raised for agricultural and food products to 10.00. This implies that farm and food products were less diversified and therefore more easily replaced by imported products. As a result, the negative effects of the Russia1 and positive effects of the Russia2 simulations eased off in South Ostrobothnia. When comparing Russia2E with Russia2, agricultural and food product exports to other destinations (besides Russia) increased and the value added of agriculture and food products increased. Simultaneously, value added of, for example, forestry decreased. Farmer wages increased while the wages of other labour groups decreased. Capital and land rents increased.

The same applies for Russia1/Russia1E in North Karelia, whereas higher elasticity values turned the Russia2E results positive also in North Karelia. When comparing Russia2E with Russia2, agricultural and food product exports to other destinations (besides Russia) increased and the value added of agriculture and food products increased. Imports of, e.g. chemicals, plastic, electronic equipment, vehicles and food products also increased along with the value added of private services. Value added of agriculture and food production dropped less than in Russia2, while value added of other manufacturing increased less than in Russia2. Economic emphasis moved towards services. Simultaneously, capital, land rents and the wages of all labour groups increased.

\footnotetext{
${ }^{5}$ In the 'Basic' projection columns, the positive and negative signs show the price trends during the projection period by products, while the 'Change' columns show the directions of changes when comparing the Russia simulations to the Basic simulations.
} 
Tab 8. Macroeconomic balances.

\begin{tabular}{|c|c|c|c|c|c|c|c|c|}
\hline & \multicolumn{2}{|c|}{$\begin{array}{l}\text { South } \\
\text { Ostrobothnia }\end{array}$} & \multicolumn{6}{|c|}{ North Karelia } \\
\hline & \multicolumn{8}{|c|}{ Difference between BASIC and RUSSIA, \% } \\
\hline & Exch & $E x c h+E$ & ROW & ROW+E & Exch & Exch+E & ROW & ROW+E \\
\hline Private consump & -0.80 & $\begin{array}{c}-0.32 \\
\end{array}$ & 3.07 & 2.71 & -0.31 & $\begin{array}{l}-0.16 \\
\end{array}$ & -0.54 & 0.38 \\
\hline Investments & $\begin{array}{ll}-1.44 \\
\end{array}$ & -0.99 & 33.69 & 25.27 & -0.90 & -0.72 & -4.25 & 4.60 \\
\hline Exports & -2.23 & -1.38 & -0.60 & -0.08 & -0.68 & -0.50 & -0.44 & -0.50 \\
\hline Imports & -2.24 & $\begin{array}{l}-1.34 \\
\end{array}$ & 6.07 & 4.84 & -0.68 & -0.46 & -1.52 & 0.73 \\
\hline GDPMP2 & -0.74 & -0.41 & 4.09 & 3.32 & -0.35 & -0.23 & -0.31 & 0.20 \\
\hline$\overline{\text { GDP at factor costs }}$ & 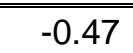 & -0.21 & 3.51 & 3.02 & $2-0.30$ & -0.18 & 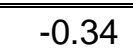 & 0.26 \\
\hline
\end{tabular}

\section{Discussion and conclusions}

The role of agriculture and food sectors in rural and regional development is a timely issue especially as the EU Member States negotiate the strategic emphasis and allocation of the future spendings between different policy areas and within the common agricultural policy. In the future, the Member States will gain more flexibility in the implementation of the CAP.

In the short/medium term, i.e. when capital availability outside of the study regions was restricted, the overall effects of the trade ban were negative for both regions. Agriculture and the food industry are key industries for the regional economy of South Ostrobothnia, not only due to their relatively large size but also due to the backward and forward linkages and indirect effects on regional economy. Albeit the total regional effects were moderate, impacts on the agricultural and food industries were substantial. In this respect, agricultural support acts as regional development support, as it maintains a basic level of population and employment also in remote rural areas. Indirectly, through its linkages, agriculture also maintains other industries and services.

The embargo moved the economic emphasis towards other industries; the forestry and metal industries in particular substituted for agriculture and food sectors as employers and economic drivers. In contrast, industries connected with or dependent on agriculture and food industries, especially distribution and transportation, faced declining value added and domestic activity. Accordingly, capital and labour moved to industries that could provide higher rents and wages. This finding is consistent with the conclusion of e.g. Olper et al. (2017), who observed that acrosssector income differences affect inter-sectoral labour migration.

When rigidities of capital availability were relaxed, even the reduction in food exports increased regional GDP and investments in South Ostrobothnia, despite a notable share of the region's local capital and work force being tied to agriculture. However, this did not apply to North Karelia, where the impacts of the food ban on the macroeconomic indicators were unambiguously negative. In North Karelia, agriculture and food industries account for only small shares of GDP and employment. This indicates the existence of a threshold after which a reduction in agricultural activities does not transform into benefits in other industries. The rigidities of labour markets and the special characteristics of agricultural capital and land become evident.

In South Ostrobothnia, the trade shock moved the economic focus towards industries that could efficiently utilise the capital injection. The construction and plastic and vehicle industries were especially capable of raising their value added. In addition, services gained and the increase in imports backed up the local distribution and transport industry. Even agriculture, to some extent, was able to catch the positive development and redirect its activities such that the value added increased. In contrast in North Karelia, other industries could not compensate the losses of agriculture and the food industry even if additional capital was available.

Due to the trade shock, farmers redirected part of their efforts to other, farm-related activities, such as tourism services and processing agricultural products, since employment opportunities for farmers in rural areas are limited. Farm diversification, forestry-related activities and commuting are options for small farm holders who choose to continue farming and remain in 
the countryside. This finding corresponds to the European Parliament's report (2016) and holds especially true for regions with relatively low levels of agriculture (European Parliament 2016; Hyytiä 2014).

The demand and supply of both rural skilled and unskilled labour increased more than those of urban labour provided that the additional capital was available. Farm work simultaneously decreased. When capital availability was scarce, all the work force groups faced decreasing wages except for 'other farm activities' in both regions. The balance between rural and urban employment did not change remarkably, as agricultural losses were compensated by other rural activities.

The rigid structure of agricultural production and support-dependency was evident when looking at the true situation in the Finnish food markets after the abolishment of the EU milk quota and the enforcement of the Russian import ban. Disregarding the trade shocks, milk production continued at the previous scale, generating oversupply, falling producer prices and farm incomes. However, farmers' incentives to react to market signals are limited, as milk production requires long-term investments in buildings, equipment and livestock. Unsurprisingly, compensation of losses was claimed and granted. Finnish dairy farmers received additional 10.7 million euro of EU subsidies for losses incurred by a Russian embargo.

This study and the CGE-model could not account for trade redirection well enough compared with, for example, gravity models (see Anderson \& Wincoop 2003). However, due the abolishment of the milk quota system of the European Union, there has been an oversupply of milk. Accordingly, finding optional markets for the Finnish products has been difficult. In 2018 (OECD), the main destinations for the Finnish animal products were France and Sweden for butter and China for concentrated milk. As for the animal product and food stuff exports that still destined to Russia, the main products were animal food preparations and living trout.

The findings indicate that the impacts caused by food import ban were dependent on the economic structure of the region and the relative position of the agriculture and food sectors within it. Even if agriculture enhances regional development by maintaining rural employment and activity, efficiency improvements and the movement of production factors to other industries could be beneficial for rural regional economies. Moreover, the growth of local services may accelerate regional growth more efficiently than export-based agriculture. The results emphasise local expertise in policy planning and implementation.

The common agricultural policy after 2021 enables the EU member states to take account of the specific needs and differences of their agricultural production (e.g. European Commission 2019). The results suggest that the agricultural support remains essential for the Finnish agriculture considering the subsidies account for one third of the farm incomes. Despite the need for the efficiency improvements and necessary redirection of the support to environmental and climate measures, traditional farm subsidies are still needed in Finland. The support maintains traditional family farm structure and ensures rural livelihood in remote rural regions.

\section{Acknowledgements}

The Finnish Cultural Foundation (No: 00170008) has supported the completion of this paper.

Academic references

[1] Anderson, J. \& Van Wincoop, E. (2003). Gravity with Gravitas: A Solution to the Border Puzzle. American Economic Review 93(1), 170-192. DOI: 10.1257/000282803321455214.

[2] Barkley, A. (1990). The determinants of the migration of labor out of agriculture in the United States, 1940-85. American Journal of Agricultural Economics 72(3), 567-573. DOI: $10.2307 / 1243025$. 
[3] Berg-Andersson, B. \& Kotilainen, M. (2016). Pakotteiden vaikutus Suomen vientiin Venäjälle [Brief No. 45]. Helsinki: The Research Institute of the Finnish Economy.

[4] Berlinschi, R., Swinnen, J. \& Van Herck, K. (2014). Trapped in agriculture? Credit constraints, investments in education and agricultural employment. European Journal of Development Research 26(4), 490-508. DOI: 10.1057/ejdr.2014.30.

[5] Bilgic, A., King, S., Lusby, A. \& Schreiner, D. F. (2002). Estimates of U.S. Regional Commodity Trade Elasticities of Substitution. The Journal of Regional Analysis and Policy 32(2), 79-98. DOI: 10.22004/ag.econ.132238.

[6] Boulanger, P., Dudu, H., Ferrari, E. \& Philippidis, G. (2016). Russian roulette at the trade table: A specific factors CGE analysis of an agri-food import ban. Journal of Agricultural Economics 67(2), 272-291. DOI: 10.1111/1477-9552.12156.

[7] Cruz, L., Ramos, P. N., Barata, E. \& Sargento, A. L. (2017). Assessing an agri-food develoment strategy: a bi-regional input-output model with resource-constrained sectors. European Review of Agricultural Economics 44(5), 860-882. DOI: 10.1093/erae/jbw028.

[8] Drabenstott, M. (2003). A new era for rural policy. Economic Review, Fourth Quarter. Kansas: Center for the Study of Rural America, Federal Reserve Bank of Kansas City, USA.

[9] Garrone, M., Emmers, D., Olper, A. \& Swinnen, J. (2019). Jobs and agricultural policy: Impacts of the common agricultural policy on EU agricultural employment. Food Policy 87, No. 101744. DOI: 10.1016/j.foodpol.2019.101744.

[10] Harrigan, F. \& McGregor, P. G. (1989). Neoclassical and Keynesian Perspectives on the Regional Macro-Economy: A Computable General Equilibrium Approach. Journal of Regional Science 29(4), 555-573. DOI: 10.1111/j.1467-9787.1989.tb01244.x.

[11] Horridge, M. (2011). The TERM model and its database [General Paper No. G-219]. Melbourne: Monash University.

[12] Hyytiä, N. (2014). Farm diversification and regional investments: efficient instruments for the CAP rural development targets in rural regions in Finland? European Review of Agricultural Economics 41(2), 255-277. DOI: 10.1093/erae/jbt022.

[13] Julia-Wise, R., Cooke, S. C. \& Holland, D. (2002). A Computable General Equilibrium Analysis of a Property Tax Limitation Initiative in Idaho. Land Economics 78(2), 207-227. DOI: $10.2307 / 3147269$.

[14] Khachaturyan, M. \& Peterson, E. W. F. (2017). The Russian Food and Agricultural Import Ban. Cornhusker Economics No. 756. Lincoln: University of Nebraska.

[15] Kilkenny, M. \& Partridge, M. D. (2009). Export Sectors and Rural Development. American Journal of Agricultural Economics 91(4), 910-929. DOI: 10.1111/j.1467-8276.2009.01320.x.

[16] Kutlina-Dimitrova, Z. (2015). The economic impact of the Russian import ban: a CGE analysis. DG TRADE Chief Economist Note 3.

[17] Liefert, W. M. \& Liefert, O. (2015). Russia's Economic Crisis and its Agricultural and Food Economy. Choices 30(1), 1-6.

[18] Lofgren, H., Harris, R. L. \& Robinson, S. (2002). Standard Computable General Equilibrium Model in GAMS. Washington DC: International Food Policy Research Institute.

[19] Niemi, J. \& Väre, M., eds., (2018). Agriculture and food sector in Finland 2018. Helsinki: Natural Resources Institute Finland.

[20] Martinho, V. (2015). Agricultural economics in the context of Portuguese Rural Development. In Martinho, V., ed., The Agricultural Economics of the 21st Century (pp. 121-136). Cham: Springer International Publishing.

[21] Mattas, K. \& Loizou, E. (2017). The CAP as a job stabiliser. EuroChoices 16(3), 23-26. DOI: $10.1111 / 1746-692 X .12170$. 
[22] Midmore, P., Partridge, M. D., Olfert, M. R. \& Ali, K. (2010). The evaluation of Rural Development Policy: Macro and Micro Perspectives. Euro Choices 9(1), 24-29. DOI: 10.1111/J.1746-692X.2010.00155.X.

[23] Olper, A., Raimondi, V., Cavicchioli, D. \& Vigani, M. (2014). Do CAP payments reduce farm labour migration? A panel data analysis across EU regions. European Review of Agricultural Economics 41(5), 843-873. DOI: 10.1093/erae/jbu002.

[24] Partridge, M. D. \& Rickman, D. S. (1998). Regional Computable General modelling: A Survey and Critical Appraisal. Regional Science Review 21(3), 205-248. DOI: 10.1177/016001769802100301.

[25] Petrick, M. \& Zier, P. (2012). Common agricultural policy effects on dynamic labour use in agriculture. Food Policy 37(6), 671-678. DOI: 10.1016/j.foodpol.2012.07.004.

[26] Richardson, H. W. (1976). Regional Economics, Location Theory, Urban Structure and Regional Change. London: Weidenfeld and Nicolson.

[27] Rizov, M., Davidova, S. \& Bailey, A. (2018). Employment effect of CAP payments in the UK non-farm economy. European Review of Agricultural Economics 45(5), 723-748. DOI: $10.1093 /$ erae/jby008.

[28] Robinson, S., Cattaneo, A. \& El-Said, M. (2000). Updating and estimating a Social Accounting Matrix using cross entropy method [TMD discussion papers 59]. Washington DC: International Food Policy Institute.

[29] Rodríguez-Pose, A. \& Gill, N. (2006). How does trade affect regional disparities? World Development 34(7), 1201-1222. DOI: 10.1016/j.worlddev.2005.12.003.

[30] Round, J. (2003). Social Accounting Matrices and SAM-Based Multiplier Analysis. In: Tool Kit; Poverty and Social Impact Analysis (pp. 1-14). Washington, DC: World Bank.

[31] Smutka, L., Spicka, J., Ishchukova, N. \& Selby, R. (2016). Agrarian import ban and its impacts on the Russian and European Union agrarian trade performance. Agricultural Economics-Czech 62(11), 493-506. DOI: 10.17221/294/2015-AGRICECON.

[32] Thomson, K., Berkhout, P. \& Constantinou, A. (2011). Balancing between structural and rural policy. In Oskam, A., Meester, G. \& Silvis, H., eds., EU policy for agriculture, food and rural areas (pp. 385-400). Wageningen Academic Publishers.

[33] Thurlow, J. (2004). A Dynamic Computable General Equilibrium (CGE) Model for South Africa: Extending the Static IFPRI Model [Working Paper 1]. Pretoria: Trade and Industrial Policy Strategies.

[34] Törmä, H. \& Lehtonen, H. (2009). Macroeconomic and welfare effects of the CAP reform and further decoupling of agricultural support in Finland: A CGE modelling approach. - Acta Agriculturae Scandinavica, Section C - Food Economics 6(2), 73-87. DOI: $10.1080 / 16507540903474673$.

[35] Törmä, H. \& Rutherford, T. (1992). A General Equilibrium Assessment of Finland's Grand Tax Reform [Reports No 15, Department of Economics and Management]. Jyväskylä: University of Jyväskylä.

[36] Vaittinen, R. (2004). Trade Policies and Integration: Evaluations with CGE-Models. Helsinki School of Economics.

[37] Wysokinski, M. \& Baran, J. (2014). The Russian Embargo: Tribulations of Dairy and Meat Exports from Poland and Other EU Member Countries. Journal of International Agricultural Trade and Development, 10(1), 135-147.

[38] Wing, I. S. (2004). Computable General Equilibrium models and their use in economy-wide policy analysis: Everything you ever wanted to know (but were afraid to ask) [technical note 6]. Cambridge, MA: Massachusetts Institute of Technology. 
[39] Bank of Finland 2017. Upswing strengthens, supported by exports - in 2019 GDP will finally exceed the level of 2008. Press release No 15. Available at: https://www.suomenpankki.fi/en/media-and-publications/releases/2017/upswingstrengthens-supported-by-exports-in-2019-GDP-will-finally-exceed-the-level-of-2008/.

[40] European Union 2018. How the EU budget is spend. Referred to 21.9.2018. Available at: https://europa.eu/european-union/about-eu/money/expenditure_en.

[41] European Commission 2013. Overview of CAP Reform 2014-2020. Agricultural Policy Perspectives Brief, No 5. DG Agriculture and Rural Development, Unit for Agricultural Policy Analysis and Perspectives. Brussels: European Commission.

[42] European Commission 2017. The Future of Food and Farming, Communication from the Commission to the European Parliament, the Council, the European Economic and Social Committee and the Committee of the Regions, COM(2017)713. Brussels: European Commission.

[43] European Commission 2019. Agricultural policy post-2020. Simplification and modernisation. European Commission.

[44] European Parliament 2014. The Russian Embargo: Impact on the Economic and Employment Situation in the EU. Employment and Social Affairs, Briefing. Policy Department A: Economic and Scientific Policy. Brussels: European Parliament.

[45] European Parliament 2016. Research for AGRI Committee - The role of the EU's Common Agricultural Policy in creating rural jobs. DG for Internal Policies. Policy Department B structural and Cohesion Policies. Brussels: European Parliament.

[46] ETLA (Elinkeinoelämän tutkimuslaitos) 2016. Suhdanne Vuosikirja 2016:2. [The Research Institute of the Finnish Economy. ETLA Forecast Year 2016:2] Helsinki: ETLA.

[47] Finnish Customs 2016. Tavaroiden ulkomaankauppa maakunnittain vuonna 2015, Kauppa 2016. [International trade in goods by Finnish regions in 2015, Trade 2016.] Finnish Customs.

[48] Finnish Customs 2018. Suomen ja Venäjän välinen kauppa. [Finnish-Russian trade]. Finnish Customs.

[49] Finnish Customs. Kauppa Suomi-EU-28, 2008-2016. [Trade between Finland and the EU 2008-2016].

[50] Finnish Customs. Kauppa Suomi-kaikki maat 2009-2016. [Trade between Finland and all foreign countries].

[51] Finnish Customs. Tullissa kannetut valtion tulot. [Government taxes and levies].

[52] LUKE Natural Resources Institute Finland. Maatalouden rakennekehitysennuste, Taloustohtori 20.6.2017. [Forecast of the structural development of agriculture, Statistics database].

[53] LUKE Natural Resources Institute Finland. Maatilojen lukumäärä alueittain 1995-2012. [Number of farms by regions in 1995-2012].

[54] OECD. The Organisation for Economic Co-operation and Development. The observatory of economic complexity. Data visualization tool for international trade data. Finland: Product trade. Available at: https://oec.world/en/profile/country/fin/.

[55] Regional Council of North Karelia. Työpaikat kunnittain, Pohjois-Karjala 1991-2013. [Work places by municipalities in North Karelia in 1991-2013].

[56] Regional Council of North Karelia. Työllinen työvoima 31.12.2014. [Employed]. 
[57] Regional Council of North Karelia and Ministry of Economic Affairs and Employment. Työttömien osuus työvoimasta keskimäärin (\%) [Approximate share of unemployed of labour force].

[58] Regional Council of South Ostrobothnia. Etelä-Pohjanmaan hyvinvoinnin tilastopaketti 2016. [Statistics of wellbeing in South Ostrobothnia in 2016].

[59] Statistics Finland. Official Statistics. Available at: http://tilastokeskus.fi/til//index_en.html.

[60] Statistics Finland. StatFin database. Available at: http://pxnet2.stat.fi/PXWeb/pxweb/en/StatFin/.

[61] U.S. Department of Agriculture. Income Elasticities Finland 1996. Economic Research Service.

[62] VATT, Institute for Economic Research (Finnish Government) 2015. Regional input-Output tables of 2008, unpublished data.

[63] WTO (World Trade Organization). Russian Federation: Tariffs and imports: Summary and duty ranges / Tariffs and imports by product groups / Exports to major trading partners and duties faced.

[64] WTO (World Trade Organization). European Union: Tariffs and imports: Summary and duty ranges / Tariffs and imports by product groups / Exports to major trading partners and duties faced.

[65] Standard Industrial Classification TOL 2008. Classification of commodities: CPA 2008. 